Article

\title{
The Extent of the Researcher's Liability for Environmental Damage Caused by Academic Research
}

\author{
Ahmad Shohani ${ }^{1, *}\left(\mathbb{D}\right.$, Elham Ataei ${ }^{1}$, Nima Norouzi ${ }^{2}(\mathbb{C}$ \\ ${ }^{1}$ School of political science and international relationships, Payam Noor University, Tehran, Iran \\ 2 School of Law, Department of Human Sciences, Islamic Azad University, Tehran, Iran \\ ${ }^{*}$ Correspondence: Ashohani1300@gmail.com
}

How to cite this paper: Shohani, A., Ataei, E., \& Norouzi, N. (2021). The Extent of the Researcher's Liability for Environmental Damage Caused by Academic Research. Research Journal of Ecology and Environmental Sciences, 1(2), 71-81. Retrieved from https://www.scipublica-

tions.com/journal/in-

dex.php/rjees/article/view/98

Received: July 20, 2021

Accepted: August 24, 2021

Published: August 25, 2021

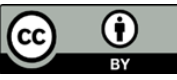

Copyright: (c) 2021 by the authors. Submitted for possible open access publication under the Creative Commons Attribution (CC BY) license

(http://creativecommons.org/licenses /by/4.0/).

\begin{abstract}
The right to the environment and the research right are human rights that must be protected. The right of individuals to a healthy environment is part of the human rights that are increasingly threatened by human activities. This right is a prominent example of solidarity rights and a prerequisite for realizing many human rights. Exercising this right requires a level of development that provides the basis for further environmental degradation. The activities of academic researchers in the direction of progress and development can pave the way for environmental damage. This article discusses when a researcher causes harm in conducting academic research. The need to compensate and support the researcher in conducting their research contrasts these two rights; Therefore, it is necessary to look for ways of compensation that make possible the simultaneous protection of these two rights. Because according to Article 21 of the Stockholm Declaration and Article 2 of the Rio Declaration, governments are responsible for ensuring that their activities do not lead to environmental damage. The key role of governments in resolving this conflict and helping to promote academic research, reducing harm, and trying to prevent this kind of harm is obvious. In this article, we intend to resolve this conflict by examining the principles of human rights, the right to research, and the right to the environment and to examine Iran's legal approach in this regard.
\end{abstract}

Keywords: Right to the environment; right to research; civil liability; Iranian law.

\section{Introduction}

As stated in the preamble to the Stockholm Declaration, man is the creator and shaper of his environment. An environment that gives him physical survival and spiritual growth (moral, social, and spiritual). Through the rapid pace of science and technology, it has been achieved in countless ways, and on an unpredictable scale, it has resulted in recognition of the right to research, which has various aspects and its support has various dimensions[1]. One of these lesser-known aspects of advocacy is the protection of the researcher against damages that may arise as a result of their research, which encourages the researcher to engage in research and development operations enshrined in international instruments such as the Covenant. International economic, social, and cultural rights are enshrined in Iran's highest domestic law, the constitution, which may harm the environment, a fundamental human right, and a platform for development. Sustainable nations. Civil and criminal liability for environmental protection is recognized, and governments are required to protect the environment of their territory; Thus, the right to research conflicts with the right to the environment[2].

On the one hand, the researcher must be supported in his research, and on the other hand, the damage that results from this research must be compensated. Finding a way to resolve this conflict is essential to upholding both of these rights. Although the right to the environment is more addressed and considered more important, this does not mean that the right to research is sacrificed and researchers are not adequately supported. In the 
meantime, the government should be obliged to adopt an appropriate method for mutual support[3-5].

Therefore, in this article, we seek to answer three questions: one (What are the theoretical foundations of protection of the right to research and the right to the environment? Two) How is it possible to resolve the conflict between these two rights? Are there rights and resolving their conflict? In answer to these questions, three hypotheses are raised: one (the right to research in the International Covenant on Economic, Social and Cultural Rights and the right to the environment in all three generations of human rights, and especially in documents The third generation of human rights is protected, such as the Stockholm Declaration of 1972; Supports, but the presumption of responsibility for the government is possible only if the researcher has an employment relationship with the government and the damages are not documented in their actions and are related to the lack of equipment of government offices and institutions[6, 7].

This article deals with the civil liability of the researcher, which results from the damage to the environment caused by academic research. A great deal of scientific research being done by universities may cause harm, sometimes environmental, while beneficial to society. As a government institution, the university can be a mediator for assigning the researcher's responsibility to the government, and in this way, better material support is provided to the environment. In this article, we also examine the environmental responsibility of researchers in Iran and discuss legal solutions to support both scientific research and the environment $[8,9]$.

The right to the environment has been discussed in detail in the Iranian legal literature. The responsibility of the government and individuals has been discussed in detail, but the right to investigate in terms of protecting the researcher from the damages it inflicts, including environmental and other damages. , Not yet discussed. This article discusses a conflict that has not received enough attention before and the right to investigate because it can violate the environmental rights of individuals by harming the environment. A solution must be found to combine these two rights[10].

\section{Natural human rights}

The article's subject is directly related to two human rights recognized by international instruments: the first is the right to research, and the second is the right to the environment. These two rights conflict with the subject matter. On the one hand, the researcher deserves support to facilitate the research process, and on the other hand, there is a possibility of damage to the environment during the research, and there should be a suitable method for compensation and, more importantly, prevention of damage and protection of the right to research. To be used. To find such a way, we first examine the foundations of these two rights and then how to compensate and resolve the conflict in support of these two rights[11].

\subsection{Right to research}

This right can be deducted from Article 15, paragraph 3 of the International Covenant on Economic, Social, and Cultural Rights. "States Parties to this Covenant respect the freedom necessary for scientific research and creative activity," the article reads. The States Parties are therefore obliged to provide the necessary freedom to conduct research. It may be said that what is inferred from paragraph 3 of Article 15 of the Covenant is merely the creation of freedom of inquiry, which can be done without interference or abandonment by the government, but as soon as the right to the inquiry is recognized, governments are obliged to provide They will be a suitable platform for scientific research. Because securing these rights requires the government not to interfere in the freedom of scientific research, and at the same time requires positive government intervention to provide facilities and monitoring for progress[12]. The right to research can be considered a subset of 
the right to education, as Article 15 of the Covenant essentially deals with the right to education.

The right to education is enshrined in many international human rights instruments, but the right to research and the freedom to conduct research are only explicitly mentioned in the International Covenant on Economic, Social, and Cultural Rights[13].

What is certain is that the right to research is a human cultural right, and even though it is not a fundamental human right, it deserves special attention under the banner of the right to education. The definition of this right can be said: "Research is a specific name for a general ability, and this ability is the transformation of regular findings into what we need to know but do not yet know, and the right to research is the right to do so."

This definition is not an obstacle and includes any awareness and knowledge required to achieve the knowledge required, both scientific and non-scientific. Although this article focuses only on scientific research related to the academic environment, this lack of inhibition can be considered a strong point because it does not limit research to operations in experimental sciences, and the broad interpretation of protectionist laws is completely justified. With this interpretation, all citizens have the right to investigate what they deem necessary[14].

In domestic law, our constitution, in paragraph 4 of the third principle, obliges the government to do all it can (to achieve the goals mentioned in the second principle) in "strengthening the spirit of inquiry, follow-up, and initiative in all scientific, technical, cultural fields." And Islam through the establishment of research centers and encouragement of researchers.

This is clearly stated in the constitution, contrary to international instruments. Among the facilities that the government should use to strengthen the spirit of research is financial facilities that provide the possibility of compensating the researcher as a researcher. Anticipating such possibilities will encourage researchers.

Therefore, the right to investigate is recognized in international human rights instruments and Iran's highest domestic law document. This mutual domestic and international support obliges the government to support researchers, removing the burden of civil liability from researchers[15, 16].

\subsection{Right to the environment}

The right to a healthy environment exists in three generations of human rights. This right is recognized as a coercive and inalienable consequence of political and civil law fundamental human rights. The right to exist, breathe, and live are some of the rights achieved in the environmental context.

Economic, social, and cultural human rights have environmental dimensions like the first generation of these rights. The right to health and the right to work in a healthy environment is among the second generation of human rights in which the environment plays an important role[16].

According to these two covenants, the right to the environment is considered a subsidiary right over other human rights. This issue has its strengths and weaknesses. Its strength is that the human right to a healthy environment will be considered one of the basic components or main effects of the rights of the first and second generations, and thus a unique feature of these two generations (such as non-suspension in the first generation and can be It will be demanded from the government in the second generation, but its weakness will be that this right will not have independence and will be known as the accessories or effects of the rights of the first and second generations.

But the third generation of human rights recognized the right to a healthy environment as an independent right. The starting point for recognizing this right should be the Declaration of the United Nations Conference on the environment or the 1972 Stockholm Declaration. The first principle of this Declaration states the human right to a healthy environment[17]: 
"Human beings have fundamental rights to liberty, equality and the satisfaction of living in an environment which enables them to live in dignity and happiness, and to maintain and improve the environment for present and future generations ... »

This principle implicitly implies the freedom of human activities, which can include freedom in the researcher's academic research, and at the same time expresses the responsibility of the individual during this research in a way that guarantees the protection of the environment. The Rio Declaration also mentions the right to development and integrating environmental protection with the development process. The country's development depends on specialized human resources due to increased scientific research[18].

What can be deduced from this principle is that the right to the environment is still recognized as the basis for human beings to enjoy their other rights, such as the right to live in this principle; But in 1982, the draft International Covenant on Civil and Political Rights recognized the right to the environment independently. The introduction to this draft states:

"Peace, development, the environment, and the common heritage of humanity are henceforth universal values that have been recognized by all human beings, races, and nations. "Their rights should be recognized, protected, and realized as human rights."

Since then, other international human rights instruments have been developed, including the 1982 Universal Charter on Nature, the African Charter on Human and Ethnic Rights, the 1988 San Salvador Protocol, and the 1992 Rio Declaration[19].

Now that we are familiar with the right to a healthy environment for the human rights family, we turn to the concept of environmental damage. It was mentioned in the introduction that researchers and writers agree that it is very difficult, if not impossible, to define the concept of the environment; But it is necessary to define the concept of environment to know the extent to which progress leads to responsibility. To provide an acceptable definition, the environment can be divided into two parts: human environment and natural environment, and a definition can be provided for each:

"Human environment or man-made environment refers to the part of the environment created by man and is the product of his thinking."

"Natural environment refers to the part of the environment that has no role in the formation of human beings, but is a God-given gift and includes forests, pastures, mountains, plains, rivers, seas, swamps, landscapes, and ... becomes. "Factors that make up the natural environment include living factors (plants and animals) and inanimate factors (soil, climate)."

But for a functional definition that involves the relationship between man and his environment can be summarized as follows[20]:

"The environment refers to the whole environment to which man is, directly and indirectly, dependent and in which his life and activities are related."

There are two approaches to defining environmental damage. The first approach looks at this type of damage from a human-centered perspective and considers environmental damage as the source of harm to humans. From this perspective, we can refer to this definition: "Environmental damage is the damage that is done to people or environmental objects around human life."

According to this definition, man is the victim of harm and not the environment, and the environment is the source of harm. In contrast to this selfish approach, there is an approach that considers the environment itself to be a victim of damage: "damage that is directly inflicted on the environment regardless of the repercussions that these damages have on property and objects[21]."

This definition has a more environmentally friendly approach, but it has a drawback, and that is that the environment is the same environment that was said to be very difficult to define. To avoid such a definition, the environment can be illustrated. The second principle of the 1972 Stockholm Declaration provides these examples. According to this article: "The natural resources of the earth, including air, water, soil, plants and animals, and 
especially specific examples of natural ecosystems, must be protected for the use of present and future generations with careful planning and proper management."

Therefore, we consider the examples mentioned in this principle as the subject of damage without defining the environment. In addition to clarifying the subject, this example explanation does not limit the concept of environment and is not limited to these cases. These are allegorical; therefore, a new example of environmental damage can be considered wherever environmental protection is required[22].

Therefore, damage to the earth's natural resources, including (not limited to) air, water, soil, plants and animals, and specific examples of natural ecosystems, regardless of its impact on humans and their property, is considered environmental damage.

The economic view of the research right also shows that it is even more important and cost-effective to provide appropriate facilities for the researcher to research further compensation, largely due to inappropriate equipment.

Thus, we see that the economic analysis of environmental compensation resulting from academic research has the same result as the human rights approach to this issue and that the government is a more appropriate person to compensate and be held responsible[23].

\section{Resolving the conflict between the two rights}

The Montreal Ozone Layer Treaty and the Climate Change Treaty, signed in Rio, stressed the need for a closer relationship and understanding between the science and technology community and policymakers. Members of the society are given a new responsibility to achieve sustainable development, and they have a new responsibility to the people that obliges them to respect the ideals of their lofty profession. Achieving agreement among scientists on professional ethics and its acceptance by the public will pave the way for better oversight of their accountability to the public. Given the need for the researcher to be responsible for the environmental damage, they inflict as an academic researcher, the first type of responsibility that comes to mind is their civil liability; That is, the researcher who caused the damage is responsible for compensating the damage, But we have seen that the government is a better compensator in terms of human rights as well as economics[24].

So we need a basis to delegate responsibility from the researcher to the government. This is also consistent with the international responsibility of the government, as in international environmental law, the government is also liable for damages caused by persons under its authority or control. By assuming the state is responsible for assuming the traditional rules of civil liability, we arrive at the rules of responsibility in public international law, which differ in basis and purpose.

The purpose of civil liability in private law is to compensate individuals with private rights, which according to the definition of environmental damage and the approach of this definition, many environmental damages will not be required by this system. Because only if these damages affect the interests of individuals and cause direct damage to them are they considered losses; But the purpose of public law is to protect the interests of society and public law issues. This goal puts prevention more important than compensation, and it is in line with the goal of environmental law.

Liability in public law is based on pure liability, but in the rules of traditional civil liability, the basis of liability in most countries is a fault or a combination of the fault and pure liability. One of the difficulties in claiming environmental damage is proving the causal relationship, which is solved by the government's responsibility, and the principle will be based on responsibility[25].

It remains to be seen what would be a more logical solution to resolve the conflict between the right to research for individuals in society and their right to the environment. Four assumptions can be made: 
A) The researcher has absolute responsibility; Two) the government has absolute responsibility; Three) The principle is the responsibility of the researcher unless proven otherwise; Four) The principle is the government's responsibility unless proven otherwise; The damage considered in this paper is the environmental damage caused by academic research. We see that the researcher has organizational affiliation and acts on behalf of the university. It is worth noting that the researcher does not pursue a profit goal in principle, and the action that takes place from him and leads to damage is an action that benefits society. The researcher's affiliation with the university paves the way for their assignment of responsibility. Administrative law discusses in detail theories that leave compensation to the government for the actions of government employees. Theories such as direct government responsibility or the theory of equality of citizens against public spending justify this[26].

But each of these assumptions has its effects and consequences. If we hold the researcher responsible, there will be abuses in supporting him and his right. Recognition of a right is associated with protecting that right, and the researcher will no longer be willing to research if they are in absolute danger of being harmed in any research. This will not have a minor effect on one person, and society will be affected. It is not far-fetched to claim that the progress and development of a society depend on its educational and research operations and that failure to support this important issue has a devastating effect on the development process of that society; Therefore, the assumption of absolute responsibility will not be helpful for the researcher[27].

In the second hypothesis, positive results can be expected from the absolute responsibility of the government. On the one hand, the government has more resources to compensate, and on the other hand, by requiring the researcher to compensate for the damage caused by the researcher, the government will take a precautionary approach to reduce the likelihood of damage caused by academic research. And research equipment and material investments and monitoring the research process will reduce the possibility of environmental damage. At the same time, this will enrich the research and compensate for the damage done to the environment. In environmental law, the prevention principle is that pollution prevention is always more cost-effective than restoring the status of a polluted area. Today, a new type of liability is considered in environmental law, called preventive liability, and it is considered necessary when there is a risk of serious damage. This type of liability is economically justified, but the government may lose its incentive to invest in research because if the researcher causes damage to the environment, whether it is to blame or not, the cost of compensation will be borne by the government or public institutions. They will go in the direction of reducing their costs, and in this regard, they will turn away from research because it is likely to be costly for them; Thus, although the absolute responsibility of the government in terms of compensation for environmental damage seems desirable, by reducing the government's incentive to develop research, it does not provide the desired context to protect the right to research[28].

The third assumption is that the principle is based on the researcher's responsibility, but it is possible to prove otherwise. This means that if the damage is the result of a fault or negligence on the part of the university on behalf of the government, it is possible to refer to this institution for compensation; However, this method of compensation does not protect the environment and the researcher because the researcher has less access to financial resources to compensate the government and the damage to the environment sometimes requires large financial resources to compensate, which is the capacity of a The researcher is outside. On the other hand, the researcher must seek to prove the government's guilt, which is a problem and requires time and money, and it is necessary to identify the right to research to protect this right, which is not compatible with this approach.

But in the fourth hypothesis, with the principle that the government's responsibility can be proven otherwise, and the researcher is responsible, better results can be achieved. 
As mentioned, the government has more resources to compensate, and there is more confidence in environmental compensation from the government than from the researcher. This assumption means that while the government takes a precautionary approach, the researcher also researches with more confidence, and since it is possible to prove his guilt and, consequently, his responsibility, his recklessness is prevented. It is clear that this approach supports both the environment and the researcher, but it must be borne in mind that proving the researcher's responsibility, in this case, must be done during a fair trial because otherwise, the government can abuse the researcher's dependence on himself. And claim damages from the researcher and receive compensation from him[29].

This approach is also consistent with the principles of international government responsibility in international law because the general principle applicable in international law is that the government is not responsible for the actions of private individuals because those actions cannot be attributed to it. However, if private individuals are represented by the government and act as government representatives, their actions can be attributed to the government. This concept applies to paragraph 2 of Article 7 of the Government's International Responsibility Plan. This paragraph provides:

"The action of the affiliated components of a unit which is not part of the official organization or internal affiliated units but has the authority to exercise part of its governmental authority under domestic law is recognized as an act of the government under international law, provided that it acts in its position[30]."

In this case, the government has two main tasks: to anticipate and prevent acts of wrongdoing and prosecute and punish the perpetrator.

In the first place, every government must take the necessary measures to prevent accidents and dangers as much as possible in its territory and to protect and protect those who are exposed to threats and dangers. Put. If the government does not take the necessary care in anticipating and preventing acts against private individuals and suffers damage, it will be held internationally responsible.

By generalizing the principles governing the international responsibility of governments, liability for environmental damage can be examined in both national and international arenas.

Therefore, the conflict between the right to the environment and the right to research caused by damage to the environment during academic research can be resolved with the principle of government responsibility and the possibility of proving otherwise to hold the researcher responsible[31-33].

\section{Iranian law}

The right to research and the right to the environment are clearly stated in our constitution. The right to the environment is enshrined in Article 50 of the Constitution. This principle's writing method has wisely chosen an environmentally friendly approach to protect the environment. While considering the environment as the right of today's and future generations, it considers its protection a public duty and activities that pollute the environment. It is forbidden to live or irreversibly destroy it. This principle makes it illegal to pollute or destroy the environment, regardless of its impact on human property. This principle is the most explicit ruling of the legislator in the field of environmental protection. It is important to note that environmental issues are a completely cross-sectoral issue. All members of society, especially organizations and institutions, should be following the power and efficiency of their organizations in preserving and maintaining the environment as a public duty of any activity. Avoid pollution or irreparable damage to the environment. Numerous environmental laws have been passed, many of which have a criminal approach to providing environmental protection. Laws such as the Law on Prevention of Air Pollution adopted in 1995, the Law on Environmental Protection and Improvement adopted in 1974 (as amended in 1993), and the Law on Prevention of Water Pollution adopted in 1995[32-35]. 
The right to investigate is also mentioned in the third principle of the constitution. Paragraph 4 of this principle of the constitution obliges the government to do all it can to achieve the goals mentioned in the second principle in "strengthening the spirit of inquiry and follow-up and initiative in all scientific, technical, cultural and Islamic fields through the establishment of research centers and Encourage researchers. This principle imposes a duty on the government to use "all its resources" in the service of developing research in the country. It has been said before that one of these possibilities could be financial facilities to be used to compensate for such damages. The constitution provides the necessary context for this issue, but a law that provides a way to implement this principle, especially in the way we want, is hard to find.

Perhaps the fund's statute for the Support of Researchers and Technologists of the country, approved by the Supreme Council of the Cultural Revolution on 10/28/2010, can be considered an example. Article 2 of this statute, to explain the purpose of this fund, states[36-39]:

"The purpose of establishing the fund is to flourish research affairs to produce science, technology, and commercialization and benefit people from their results, by providing support and material and spiritual support and services to Iranian seminary and university researchers and technologists, both real and "It is legal."

The first objection seems to limit the support to researchers and technologists in the field and the university, and this fund does not cover independent researchers. Since the subject of the present study is academic research, this objection will be ineffective, but it is worth considering.

Note 1 of the same article, in explaining the material support, says:

"Material support is the provision of credit and facilitation of the steps and mechanism of budget allocation to researchers and technologists regarding the plans and programs submitted and approved by the fund[40]."

This note implies that material support is limited to financing the project, and this credit cannot offset subsequent losses.

But another law that can be mentioned in the law of protection of companies and institutions based on knowledge and commercialization of inventions and innovations. As its name implies, this law protects companies and research institutes, and if a researcher wants to use the benefits of this law, he must be covered by these institutes. The protection referred to in this article, i.e., facilities for environmental damage compensation, is not directly mentioned in this law. Still, in paragraph (e) of Article 3 of this law, in explaining the support and facilities granted to companies and institutions, we read:

"Creating appropriate insurance coverage to reduce the risk of products and achievements of knowledge, innovation, and technology in all stages of production, supply, and use."

It is possible to extend this insurance coverage to the risks posed by the investigation process by looking away from the legislator, and therefore to cover the damages caused by the investigation, including environmental damages. In any case, it does not seem that the legislator has such an intention, and according to the current laws of Iran, although the context of such protection can be seen, there is no specification in this regard.

Therefore, to find a solution to the conflict between the right to research and the right to the environment in Iranian law, one must refer to the traditional rules of civil liability. We know that in Iranian law, civil liability is based on fault, and on the other hand, it is difficult to claim that mere environmental damage can be claimed under existing laws. According to Article 11 of the Civil Liability Law, if the investigator has committed a mistake, he must compensate for the damage. The same article provides a basis for holding the government accountable if certain conditions are met[41]:

"Employees of the government and municipalities and their affiliated institutions who intentionally or as a result of negligence cause damage to persons on the occasion of performing their duties are personally responsible for compensating the damage, but if 
the damage is not documented by their actions and is related to defects in office equipment and "In this case, the compensation is the responsibility of the relevant department or institution, but in the case of government sovereignty, the government will not have to pay damages if the measures taken following the law as necessary to ensure social benefits and cause other harm."

This article assumes that the principle is possible on the researcher's responsibility and proves the opposite, i.e., the government's responsibility. In the next article of this law, we read[42]:

"Employers who are subject to the labor law are responsible for compensating the damages caused by the administrative staff or their workers during the work or on occasion unless it is proven that all the precautions required by the circumstances of the case are implemented. Or that if they had taken the necessary precautions, it would still not have been possible to prevent the loss. "The employer can go to the person who caused the damage if he is found liable following the law."

This article is comparable to our discussion in that it puts the principle on the responsibility of the employer, which can also include the government, and considers the possibility of proving otherwise to mean the responsibility of the worker. The legislature can take the same approach to researchers so that workers' support is conceivable[43].

\section{Conclusions}

Man must constantly be gaining experience and working on the path of exploration, invention, and progress. In our time, the power of man to transform his surroundings, if used wisely, can bring development benefits and the opportunity to improve life for all people, and if used incorrectly or carelessly, the same power can cause harm. Enter several human beings and the human environment. In discussing the principles of human rights, the right to research, and the right to the environment, the strong foundation of these two rights and the need to protect them were studied, and we saw how these two rights could conflict with each other. Following this conflict, efforts should be made to find the best way to compensate for damage to the environment during research operations. Considering the basics of human rights and economic analysis, we saw that the researcher must have security of mind to conduct his research, and the environment must be considered the most reliable compensation. Therefore, by using the researcher's employment relationship and their organizational affiliation) through the university (compensation) can be left to the government, but the absolute responsibility of the government will also have negative consequences.

On the other hand, the government, which finds itself obliged to compensate in any case, loses its motivation to develop research, and this method destroys the balance of protection of both rights. It wins because although the government's significant resources offset the damage to the environment, research will be ruthless because it loses its economic value to the government, so we must look for a way to provide security for the researcher. He should not be completely exempt from compensating for his faults so that the government has enough incentive to invest in the research sector. If there is a deliberate fault, the researchers should not be reckless, and the government should not ignore the research.

In Iranian law, the issue of research and environment in domestic documents has been considered, and the constitution has recognized both of these rights and considered it necessary to protect them; however, regarding the responsibility of the researcher, one should rely on the traditional rules of civil liability, which are based on fault and the culprit is obliged to compensate. The only basis for our rights to hold the government accountable is Article 11 of the Civil Liability Law. This article considers the conditions attributable to the government, the first of which is the existence of an employment relationship between the researcher and the government. The second is the non-fault of the researcher and the attribution of the damage to the defect of government facilities. The 
composition of this article is such that the opposite gives the result we have obtained according to the theoretical foundations, in the sense that the principle is the researcher's responsibility unless proven otherwise. It is to be hoped that the possibility of government liability is foreseen. Still, this limited liability of the government does not seem to be sufficient, and the legislature can explicitly support researchers in the same way as in Article 12 of the same law on workers' liability. Predict the method.

Because the damage should not go unrepaired and the fact that the environmental damage is irreparable and unpredictable does not lead to non-compensation and to support researchers for freedom of research, and the commitment of governments to create the right environment for activity Research funds, insurance funds, and compensation budgets in universities should be provided.

\section{Supplementary Materials: "Not applicable."}

Author Contributions: "Conceptualization, AS and EA; validation, NN, EA, and AS; formal analysis, EA.; investigation, EA.; resources, NN.; writing-original draft preparation, NN.; writing-review and editing, AS.; visualization, EA.; supervision, NN.; project administration, NN. All authors have read and agreed to the published version of the manuscript."

Funding: "This research received no external funding."

Data Availability Statement: “Not applicable."

Acknowledgments: “Not applicable."

Conflicts of Interest: "The authors declare no conflict of interest."

\section{References}

[1] Bevir, M. Key Concepts in Governance; SAGE Publication Ltd.: Los Angeles, CA, USA, 2009.

[2] Zoeteman, K.; Wijen, F.; Pieters, J. Globalization and National Environmental Policy: An Overview. In A Handbook of Globalization and Environmental Policy; Wijen, F., Zoeteman, K., Pieters, J., Eds.; Edward Elgar: Cheltenham, UK, 2005 ; pp. 1-32.

[3] Chambers, W.B.; Green, F.J. Introduction: Toward and Effective Framework for Sustainable Development. In Reforming International Environmental Governance; Chambers, B.W., Green, J.F., Eds.; UNU Press: Tokyo, Japan; New York City, NY, USA; Paris, France, 2005; pp. 1-12.

[4] Techera, J.E. Marine Environmental Governance; Routledge: Abingdon, UK, 2012; p. 283.

[5] Mauerhofer, V. The 'Governance-Check': Assessing the Sustainability of Public Spatial Decision-Making Structures. Land Use Policy 2013, 30, 328-336.

[6] North, C.D. Institutions, Institutional Change, and Economic Performance; Cambridge University Press: Cambridge, UK, 1990; p. 152.

[7] Faundez, J. Douglass North's Theory of Institutions: Lessons for law and development. Hague J. Rule Law $2016,8,373-419$. Available online: http://wrap.warwick.ac.uk/84086 (accessed on 18 October 2017).

[8] Jardin, M. Global Biodiversity Governance: The Contribution of the Main Biodiversity Related Conventions. In Global Governance of Biodiversity: New Perspectives on a Shared Challenge; Billé, R., Chabason, L., Chiarolla, C., Jardin, M., Kleitz, G., Le Duc, J.P., Eds.; IFRI: Paris, France, 2010; Available online: www.ifri.org/downloads/hereport6biodiversitygouvernance.pdf (accessed on 16 May 2012).

[9] Mauerhofer, V.; Nyacuru, F. Biodiversity, Migratory Species and Natural Heritage. In Routledge Handbook of Global Environmental Politics; Harris, P.G., Ed.; Routledge Taylor and Francis Group: Abingdon, UK, 2014.

[10] Rosendal, K.; Tvedt, M.W. Biological Diversity. In Encyclopedia of Global Environmental Governance and Policies; Pattberg, P., Zelli, F., Eds.; Edward Elgar: Cheltenham, UK, 2015; pp. 322-328.

[11] Koester, V. The Five Global Biodiversity-Related Conventions: A Stocktaking. Rev. Eur. Community Int. Environ. Law 2002, 11, 96-103.

[12] Davidson, N.; Coates, D. The Ramsar Convention and Synergies for Operationalizing the Convention on Biological Diversity's Ecosystem Approach for Wetland Conservation and Wise Use. J. Int. Wildl. Law Policy 2011, 14, 199-205.

[13] Gagnon-Legare, A.; Le Prestre, P. Explaining Variations in the Subnational Implementation of Global Agreements: The Case of Ecuador and the Convention on Biological Diversity. J. Environ. Dev. 2014, 23, 220-246.

[14] Sand, H.P. Whither CITES? The Evolution of a Treaty Regime in the Borderland of Trade and Environment. Eur. J. Int. Law 1997, 1, 29-58. 
[15] Gomar, J.O.V.; Stringer, L.C. Moving Towards Sustainability? An Analysis of Cites' Conservation Policies. Environ. Policy Gov. 2011, 21, 240-258.

[16] Koester, V. The Biodiversity Convention Negotiation Process and Some Comments on the Outcome. Environ. Policy Law 1997, 27, 175-192.

[17] Swanson, T. Why Is There a Biodiversity Convention? The International Interest in Centralized Development Planning. Int. Aff. $1999,75,307$.

[18] Chandra, A.; Idrisova, A. Convention on Biological Diversity: A Review of National Challenges and Opportunities for Implementation. Biodivers. Conserv. 2011, 20, 3295-3316.

[19] Harrop, S.R.; Pritchard, D.J. A Hard Instrument Goes Soft: The Implications of the Convention on Biological Diversity's Current Trajectory. Glob. Environ. Change-Hum. Policy Dimens. 2011, 21, 474-480.

[20] Glowka, L. Complementarities between the Convention on Migratory Species and the Convention on Biological Diversity. J. Int. Wildl. Law Policy 2000, 3, 205-252.

[21] Lenten, B. A Flying Start for the Agreement on the Conservation of African-Eurasian Migratory Waterbirds (Aewa). J. Int. Wildl. Law Policy 2001, 4, 159-164.

[22] Lenten, B. The Role of the Aewa in Phasing out Lead Shot for Hunting in Wetlands. Bird Conserv. Int. $2005,15,161-163$.

[23] Battini, S. The Procedural Side of Legal Globalization: The Case of the World Heritage Convention. Icon-Int. J. Const. Law 2011, 9, 340-368.

[24] Plant treaty 2011. Plant treaty news. In Proceedings of the 4th Meeting of the Treaty's Governing Body, Bali, Indonesian, 14-18 March 2011; Available online: http://www.planttreaty.org/content/planttreaty-news-leading-field-0 (accessed on 14 August 2012).

[25] Plant treaty 2012. 2012 International Treaty on Plant Genetic Resources for Food and Agriculture. Available online: http://www.planttreaty.org/list_of_countries (accessed on 15 May 2012).

[26] Navid, D. The International-Law of Migratory Species - The Ramsar Convention. Nat. Resour. J. 1989, 29, 1001-1016.

[27] Farrier, D.; Tucker, L. Wise Use of Wetlands under the Ramsar Convention: A Challenge for Meaningful Implementation of International Law. J. Environ. Law 2000, 12, 21.

[28] Goodwin, E.J. Chapter V.9. Convention on Wetlands of International Importance, Especially as Waterfowl Habitat 1971 (Ramsar). In Elgar Encyclopedia of Environmental Law; Faure Michael, Ed.; Edward Elgar: Cheltenham, UK, 2017; pp. 101-108.

[29] Mauerhofer, V.; Kim, R.E.; Stevens, C. When Implementation Works: A Comparison of Ramsar Convention Implementation in Different Continents. Environ. Sci. Policy 2015, 51, 95-105.

[30] Kelly, J.P. The Seduction of the Appellate Body: Shrimp/Sea Turtle I and Ii and the Proper Role of States in WTO Governance. Cornell Int. Law J. 2005, 38, 459-491.

[31] Esty, D.C. Governing the Trade-Environment Interface, WTO Law; UNU Press: Tokyo, Japan; New York, NY, USA; Paris, France, 2008; pp. 115-127.

[32] Vranes, E. Trade and the Environment: Fundamental Issues in International and WTO Law, and Legal Theory; Oxford University Press: Oxford, UK, 2009; p. 441.

[33] Nair, M.D. Trips, WTO and IPR: Biodiversity Protection-A Critical Issue. J. Intellect. Prop. Rights 2011, 16, 519-521.

[34] Sandford, R. International Environmental Treaty Secretariats: A Case of Neglected Potential? Environ. Impact Assess. Rev. 1996, $16,3-12$.

[35] Biermann, F.; Bauer, S. Assessing the Effectiveness of Intergovernmental Organisations in International Environmental Politics. Glob. Environ. Chang. 2004, 14, 189-193.

[36] Siebenhuener, B. International Bureaucracies. In Encyclopedia of Global Environmental Governance and Policies; Pattberg, P., Zelli, F., Eds.; Edward Elgar: Manchester, UK, 2015; pp. 206-212.

[37] Koetz, T.; Bridgewater, P.; van den Hove, S.; Siebenhuener, B. The Role of the Subsidiary Body on Scientific, Technical and Technological Advice to the Convention on Biological Diversity as Science-Policy Interface. Environ. Sci. Policy 2008, 11, 505516.

[38] Siebenhuener, B. Administrator of Global Biodiversity: The Secretariat of the Convention on Biological Diversity. Biodivers. Conserv. 2007, 16, 259-274.

[39] Cooney, R. Cites and the CBD: Tensions and Synergies. Rev. Eur. Community Int. Environ. Law 2001, 10, $259-267$.

[40] Rogge, S.; Reichardt, K. Policy mixes for sustainability transitions: An extended concept and framework for analysis. Res. Policy 2016, 45, 1620-1635.

[41] Chasek, P.S. Earth Negotiations: Analyzing Thirty Years of Environmental Diplomacy; UNU Press: Tokyo, Japan; New York City, NY, USA; Paris, France, 2001; p. 291.

[42] Siebenhuener, B. The Biodiversity Secretariat: Lean Shark in Troubled Waters. In Managers of Global Change: The Influence of International Environmental Bureaucracies; MIT Press: Cambridge, UK, 2009; pp. 265-291.

[43] Mauerhofer, V. A Bottom-up 'Convention-Check' to Improve Top-Down Global Protected Area Governance. Land Use Policy 2011, 28, 877-886. 